\title{
Az egyirányú blokk jelentősége pulmonalis vénaizoláció során
}

\author{
Sándorfi Gábor', Sárközy Andrea² \\ 1Debreceni Egyetem, Klinikai Központ, Kardiológiai és Szívsebészeti Klinika, Debrecen \\ ${ }^{2}$ Department of Cardiology, Electrophysiology Section, University Hospital Antwerp, Antwerp, Belgium
}

Levelezési cím: Dr. Sándorfi Gábor, 4032 Debrecen, Móricz Zs. körút 22. E-mail: sandorfidr@gmail.com

Esetünkben a pulmonalis vénaizoláció $(P V I)$ során ritkán kialakuló unidirekcionális blokkot mutatunk be. A jobb oldali tüdővénák (RPV) körkörös ablációját követöen a pulmonalis vénából ingerelve lokális elektromos aktivitás látható a vénában a pitvarba történő vezetődés nélkül. A pitvari ingerlés során azonban folyamatos, vezetődés látható a vénába. Esetünk egyedülálló példája egy szokatlan egyirányú blokknak.

Kulcsszavak: pitvarfibrilláció, pulmonalis vénaizoláció, unidirekcionális blokk

Importance of the unidirectional block during pulmonary vein isolation

Our case shows of a rare unidirectional pulmonary vein (PV) exit conduction block during pulmonary vein isolation (PVI) procedure. Following circumferential antral ablations around the right pulmonary veins (RPVs), pacing the PV showed local capture without conducting to atrium. Meanwhile pacing the atrium showed continuous presence of PV potentials. Our case is a unique example of unidirectional block in the unusual direction.

Keywords: unidirectional block, atrial fibrillation, pulmonary vein isolation

\section{Bevezetés, elméleti háttér}

A tüdővénák elektromos elszigetelése, izolációja a bal pitvartól elfogadott módja a paroxizmális és perzisztens pitvarfibrilláció kezelésének (1). A beavatkozás során a jobb v. femoralison keresztüli behatolásból diagnosztikus katétert juttatunk a sinus coronariusba, valamint az interatrialis septumon végzett punkciót követően lasso-katétert vezetünk a tüdővénákba. Az ablációs katéterrel a vénapárok körül végzett körkörös ablációs vonalak kialakítása után történik a kétirányú, bidirekcionális blokk igazolása, ami mutatja a pulmonalis vénák (PV) elektromos izolációját a bal pitvartól. Amennyiben az izoláció teljes, a vénákban történő elektromos ingerlés nem okoz aktivációt a bal pitvarban, és a bal pitvar ingerlése sem eredményez elektromos aktivitást a tüdővénákban. Az egyirányú, unidirekcionális blokknak két típusa lehet. A gyakoribb a vénába történő vezetődés blokkolódását jelentő entrance blokk, míg a másik a vénából a pitvarba történő blokkolódás, az exit blokk, amelynek során a vénát elektromosan ingerelve a pitvarban nem jelentkezik elektromos aktivitás. Az exit blokk jelenléte egy nagyon ritka jelenség a PV-k ablációját követően.

\section{Esetismertetés}

Esetünkben egy 71 éves, paroxizmális pitvarfibrillációban szenvedő beteg pulmonalis vénapárjainak körkörös ablációját végeztük el. A bidirekcionális blokk igazolása alatt a jobb felső tüdővénába helyezett lasso-katétert ingerelve (Lasso 7-8-as pólus, 800 ms ciklushossz) elektromos aktivitás látható a vénában (1. ábra, nyilak a Lasso P, Lasso 3-4 és Lasso D-pólusokon az 1. ütésnél), ami nem vezetődik a pitvarra, hiszen a pitvari aktivitást mutató CS-katéteren nem jelenik meg a véna aktivációját követően elektromos aktivitás, vagyis exit blokk van jelen. A pitvarban ezalatt hosszabb ciklushosszú sinusritmus látható, ami a vénában végzett 


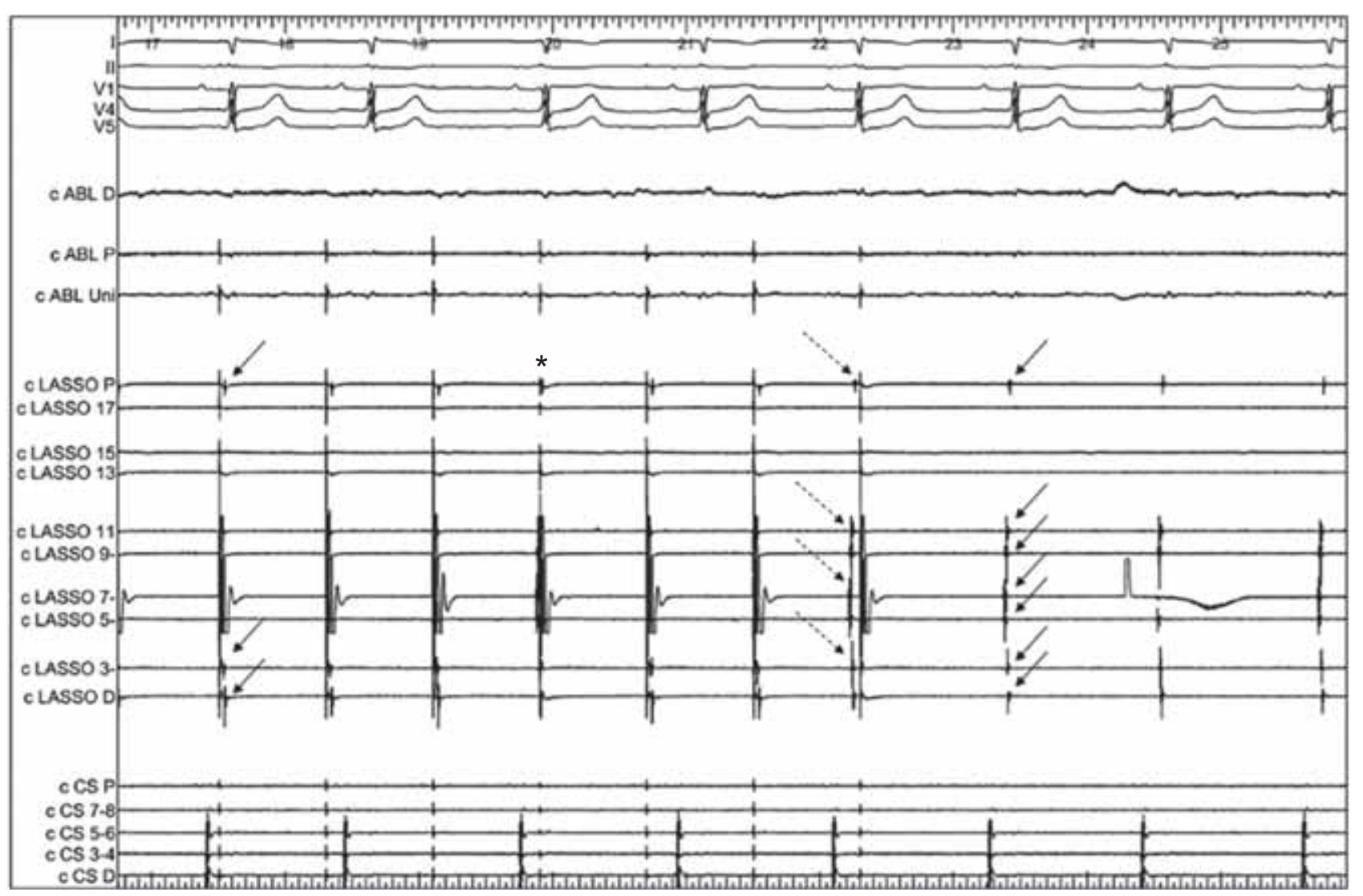

1. ÁBRA. A jobb tüdővénában elhelyezett lasso-katéter 7-8 pólusáról történő ingerlést mutató intrakardiális elektrogram. Magyarázat a szövegben. LASSO=lasso-katéter a jobb oldali tüdővénában ( $\mathrm{P}=$ proximális, $\mathrm{d}=$ =distalis), $\mathrm{CS}=$ sinus coronarius katéter ( $\mathrm{P}=$ proximális, $\mathrm{D}=$ distalis). Papírfutási sebesség: $50 \mathrm{~mm} / \mathrm{s}$

magasabb frekvenciájú ingerléstől független. A negyedik ütés (csillag) egy sinusütés, ami a vénába vezetődik, ezért az ezt követő, lasso-katéterről való ingerlés ineffektív marad a véna refrakteritása miatt. Hasonlóan a hetedik ütés is egy sinusütés, ami aktivációt okoz a vénában (szaggatott nyilak) közvetlenül a következő vénastimulus előtt, ami így ineffektív lesz. A pitvarról a vénába történő elektromos vezetést bizonyítja a lasso-katéteren keresztül történő ingerlés leállítását követően látható sinusütések vénában történő vezetődése is (8-10 ütések, nyilak a 8. ütésnél). Mindezen megfigyelések a pitvarról a vénába történő elektromos vezetés meglétét, és a vénából a pitvarra irányuló elektromos aktiváció hiányát bizonyítják.

\section{Megbeszélés}

Az unidirekcionális exit blokk egy igen ritka jelenség, a pulmonalis vénaizolációk mintegy 0,6\%-ában figyelhető meg (2). Anatómiai okok miatt sokkal gyakoribbnak kellene lennie, de valószínúleg a klinikai gyakorlat mi- att fordul elő kevesebbszer. A gyakorlat szerint ugyanis először a pitvarból a vénába történő vezetés blokkolásának az ellenőrzése történik meg, majd ezt követi az exit blokk ellenőrzése.

Mindezek alapján az exit blokk megléte önmagában még nem jelenti a tüdővéna elektromos izolációját, szükség van az entrance blokk igazolására és elérésére is, akár további ablációk végzésével, hogy a pulmonalis vénák a pitvartól elektromosan teljesen izoláltak legyenek, így csökkentve a pitvarfibrilláció további kialakulásának esélyét.

Irodalom

1. Calkins H, Kuck KH, Cappato R, et al. 2012 HRS/EHRA/ECAS Expert Consensus Statement on Catheter and Surgical Ablation of Atrial Fibrillation: recommendation for patient selection, procedural techniques, patient management and follow-up, definitions, endpoints, and research trial design. Europace 2012; 14: 528-606. doi: 10.1093/europace/eum120

2. Duytschaever M, De Meyer G, Acena M, et al. Lessons from dissociated pulmonary vein potentials: entry blokk implies exit blokk. Europace 2013; 15: 805-812. doi: 10.1093/europace/eus353 